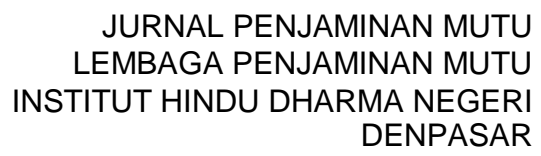

JURNAL PENJAMINAN MUTU

LEMBAGA PENJAMINAN MUTU

INSTITUT HINDU DHARMA NEGERI

DENPASAR

Volume 5 Nomor 1 Februari 2019

ISSN : 2407-912X (Cetak)

ISSN : 2548-3110 (Online)

http://ejournal.ihdn.ac.id/index.php/JPM

\title{
PENINGKATAN MUTU PENDIDIKAN TINGGI HUKUM BERBASIS PANCASILA
}

\author{
Oleh \\ I Putu Sastra Wibawa \\ Universitas Hindu Indonesia Denpasar \\ sastra@unhi.ac.id
}

diterima 12 Oktober 2018, direvisi 14 Pebruari 2019, diterbitkan 28 Februari 2019

\begin{abstract}
Human development with cross-cultural characteristics is one of them can be done by optimizing the higher education law that has the character of Pancasila. Pancasila has values that must be internalized into legal higher education that are spread throughout the existing courses. Pancasila values are systems that cannot be separated from one another. One form of effort to build a higher education law with Pancasila character by incorporating the principles of legal pluralism in the legal studies conducted.
\end{abstract}

\section{Keywords: Higher Education Law, Pancasila}

\section{PENDAHULUAN}

Upaya membangun karakter bangsa mengalami pasang surut sejalan dengan pergulatan bangsa dalam menentukan arah perjuangan dan juga arah pembangunan. Pada era pasca kemerdekaan, Indonesia diwarnai oleh pergulatan politik, terutama menyangkut pesoalan ideology Negara yang akan menentukan wujud dan jatidiri bangsa di masa depan. Sejak saat itu semangat untuk membangun kultur dan jatidiri berbasis Pancasila semakin menguat, namun dalam perjalanannya pembangunan yang terlampau berorientasi pada materi telah menumbuhkan kultur yang tidaksejalan dengan kultur yang ingin dikembangkan.

Salah satu aspek penting yang seakan-akan ditinggalkan adalah pembangunan pendidikan karakter bangsa yang telah mengakibatkan goncangan dan krisis budaya, yang kemudian berakibat pada lemahnya ketahanan budaya bangsa. Lemahnya ketahanan budaya yang ditunjukkan oleh terjadinya gejala krisis identitas yang berkembang secara berlebihan cenderung memicu konflik diberbagai bidang kehidupan. Krisis multidimensi yang berkepanjangan semakin melemahkan kepercayaan diri dan kebanggaan sebagai suatu bangsa. Menipisnya semangat nasionalisme juga sebagai akibat dari lemahnya kemampuan bangsa dalam mengelola keragaman yang merupakan realitas yang obyektif. Konsepsi Bhinneka Tunggal Ika merupakan acuan dalam mengelola kemajemukan. 
Sebagai dasar Negara (ground norm)nya bangsa Indonesia, Pancasila telah terbukti sebagai salah satu media pemersatu dalam kehidupan bermasyarakat, berbangsa dan bernegara di Indonesia. Melalui kelima sila yang terkandung didalam Pancasila, menjadikan pondasi kehidupan bernegara di Indonesia menjadi kokoh terhadap ancaman yang datang baik dari luar maupun dari dalam. Dalam konteks hukum, khususnya dalam pembentukkan peraturan perundangundangan, Pancasila semestinya diletakkan dalam wilayah sumber hukum materiil dari pembentukkan peraturan perundangundangan (Oksep Adhayanto, 2015).

Karakter adalah kumpulan tata nilai yang menuju pada suatu system,yang melandasi pemikiran, sikap, dan perilaku yang ditampilkan. Karakter menunjukkan bagaimana seseorang bertingkah laku. Karakter bangsa sebagai kondisi watak yang merupakan identitas bangsa atau identitas nasional. Identitas nasional suatu bangsa tidak dapat dilepaskan dari dukungan faktor objektif. Karakter suatu bangsa akan berkembang berdasarkan pengalaman dalam sejarah bangsa dan akan terbangun atau tidak sangat tergantung kepada bangsa itu sendiri. Pembentukan karakter merupakan aspek penting dalam bidang pendidikan tak terkecuali pendidikan tinggi hukum. Pertanyaan kemudian muncul bagaimanakah pendidikan tinggi hukum berkarakter budaya bangsa tersebut?

\section{PEMBAHASAN}

\subsection{Pancasila Sebagai Karakter Pendidikan Tinggi di Indonesia}

Membahas tentang pendidikan tinggi yang berkarakter budaya bangsa Indonesia perlu dirujuk Undang-undang Republik Indonesia Nomor 12 Tahun 2012 Tentang Pendidikan Tinggi pada Pasal 1 angka 2 yang menyatakan Pendidikan Tinggi adalah jenjang pendidikan setelah pendidikan menengah yang mencakup program diploma, program sarjana, program magister, program doktor, dan program profesi, serta program spesialis, yang diselenggarakan oleh perguruan tinggi berdasarkan kebudayaan bangsa Indonesia. Berdasarkan pasal tersebut terdapat kata kunci kebudayaan bangsa Indonesia sebagai dasar pendidikan tinggi di Indonesia. Pancasila sebagai dasar budaya bangsa tentunya menjadi dasar dalam pendidikan tinggi hukum di Indonesia. Karakter Pancasila yang lintas budaya atau multikultur sangat relevan dengan cita-cita mencerdaskan kehidupan bangsa yang berkarakter Pancasila. Pancasila sebagai pandangan hidup bangsa Indonesia tentu mengalami berbagai kendala dari waktu ke waktu. Ideologi pancasila yang digunakan sebagai dasar hukum Negara Indonesia tentu membutuhkan proses yang sangat luar biasa (Sutrisno, 2016).

Pancasila sebagai karakter pendidikan tinggi hukum di Indonesia bukannya tanpa alasan yang kuat. Pancasila memiliki keterkaitan antara satu sila dengan sila lainnya. Nilai yang tertinggi dari Pancasila yakni, nilai Ketuhanan yang kemudian menjiwai nilai-nilai lainnya, misalnya nilai Ketuhanan yang berkemanusiaan, nilai Ketuhanan yang nasionalistis, nilai Ketuhanan yang berkemasyarakatan, serta nilai Ketuhanan yang berkeadilan. Argumentasi tersebut di bangun dari konsep menjiwai dan dijiwai, Sila 1 menjiwai sila 2, 3,4 dan 5, Sila ke 2 dijiwai sila 1, dan menjiwai sila 3, 4 dan 5, begitu seterusnya. Sila kelima; Keadilan sosial bagi seluruh rakyat Indonesia diliputi dan dijiwai oleh sila-sila Ketuhanan Yang Maha Esa, Kemanusiaan yang adil dan beradab, persatuan Indonesia, kerakyatan yang dipimpin oleh hikmat kebijaksanaan dalam permusyawaratan/perwakilan.

$$
\text { Melihat ke belakang (sejarah) }
$$
lahirnya Pancasila dalam suasana kebatinan untuk melawan kolonialisme dan imperialisme, sehingga diperlukan persatuan dan persaudaraan di antara komponen bangsa. Sila pertama dalam Pancasila "Ketuhanan Yang Maha Esa" menjadi faktor penting untuk mempererat persatuan dan persaudaraan, karena sejarah bangsa Indonesia penuh dengan penghormatan terhadap nilai-nilai "Ketuhanan Yang Maha Esa" (Sastra Wibawa, 2016a). 
Kerelaan untuk menghapus kalimat "dengan kewajiban menjalankan syariat Islam bagi pemeluk-pemeluknya" oleh golongan mayoritas setelah "Ketuhanan Yang Maha Esa" pada saat pengesahan UUD pada 18 Agustus 1945 merupakan usaha untuk menjaga dan memelihara persatuan dan persaudaraan antarsemua komponen bangsa. Menarik pula untuk di lihat hasil Seminar Pancasila ke-1 Tahun 1959 di Yogyakarta berkesimpulan bahwa sila "Ketuhanan Yang Maha Esa" adalah sebab yang pertama atau causa prima dan sila "Kerakyatan yang dipimpin oleh hikmat kebijaksanaan permusyawaratan/perwakilan" adalah kekuasaan rakyat dalam kehidupan berbangsa dan bernegara untuk melaksanakan amanat negara dari rakyat, negara bagi rakyat, dan negara oleh rakyat. Ini berarti, "Ketuhanan Yang Maha Esa" harus menjadi landasan dalam melaksanakan pengelolaan negara dari rakyat, negara bagi rakyat, dan negara oleh rakyat.

Ketuhanan dalam kerangka Pancasila mencerminkan komitmen etis bangsa Indonesia untuk menyelenggarakan kehidupan public-politik yang berlandaskan nilai-nilai moralitas dan budi pekerti yang luhur. Pembukaan UUD 'negara berdasar atas Ketuhanan Yang Maha Esa menurut dasar kemanusiaan yang adil dan beradab'. Berdasarkan pokok pikiran ini, UUD harus mengandung isi yang mewajibkan pemerintah dan lain-lain penyelenggara Negara, untuk memelihara budi-pekerti kemanusiaan yang luhur dan memegang teguh cita-cita moral rakyat yang luhur.

\subsection{Pendidikan Tinggi Hukum Berkarakter Pancasila}

Pendidikan tinggi hukum yang berkarakter Pancasila diharapkan akan menghasilkan pendidikan karakter yang menjunjung tinggi nilai kemanusiaan, nilai persatuan, nilai demokrasi dan nilai keadilan yang didasarkan atas nilai Ketuhanan Yang Maha Esa. Ilustrasi dari hal tersebut dapat dilihat dalam ragaan di bawah ini:

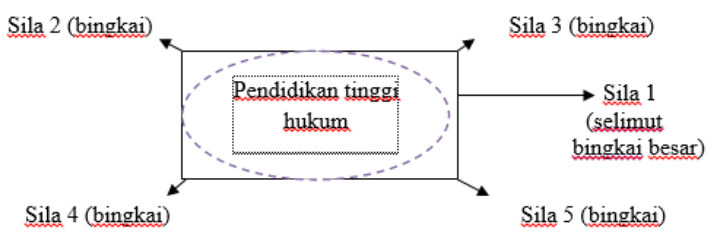

Bagan 1:

Pendidikan Tinggi Hukum Berkarakter Nilai

Pancasila

Pendidikan tinggi hukum tidak dilarang untuk mempelajari semua tradisi hukum yang ada ada di dunia, baik itu tradisi hukum agama, tradisi hukum eropa continental, maupun tradisi hukum aglosaxon, namun harus tetap juga membangun tradisi hukum yang berkarakter Pancasila sebagai ciri khas pendidikan tinggi hukum di Indonesia.

Pendidikan hukum harus mengintrodusir cara pandang baru yang mengutuhkan (holisitik), sehingga pendidikan hukum bukan untuk melahirkan manusia yang kompetitif dan mampu bersaing melainkan lulusan yang mampu mendistribusikan nilai-nilai ilahiah seperti keadilan, kebenaran, dan kejujuran sebagai dasar eksistensi hukum untuk menjadi alat perekat sosial (social unity). Ilmu pada dasarnya harus mampu memberi pencerahan pada komunitas yang dilayani (Hafidz, 2018).

Pancasila mengandung unsur-unsur yang baik dan cocok dengan nilai khas budaya Indonesia yang sudah hidup di kalangan masyarakat selam berabad-abad. Konsepsi prismatik minimal meliputi empat hal yaitu Pertama, Pancasila memuat unsur yang baik dari pandangan individualisme dan kolektivisme. Kedua, Pancasila mengintegrasikan konsep negara hukum rechtstaat yang menekankan pada civil law dan kepastian hukum dan konsep negara hukum rule of law yang menekankan pada common law dan rasa keadilan. Ketiga, Pancasila menerima hukum sebagai cermin rasa keadilan yang hidup di masyarakat (living law). Keempat, Pancasila menganut paham religious nation state, tidak menganut atau dikendalikan oleh satu agama tertentu 
(negara agama) tetapi juga tidak hampa agama (negara sekuler) karena negara harus melindungi dan membina semua pemeluk agama tanpa diskriminasi karena kuantitas pemeluknya (Amarini, 2017).

Pancasila merupakan landasan utama dalam pembuatan hukum (Peraturan Perundang-Undangang) baru maupun dengan penggantian hukum lama (politik hukum), sehingga nilai-nilai Ketuhanan, Kemanusiaan dan Kemasyarakatan (nasionalistik; demokratik; berkeadilan sosial) harus teraktualisasi kedalam substansi hukum, struktur hukum maupun kultur hukum yang akan dibangun, diharapkan dapat menguatkan integrasi bangsa, demokratisasi hukum, tercapainya kesejahteraan dan keadilan sosial dengan menempatkan Pancasila, mulai dari nilai, tujuan sampai dengan aktualisasi kepada berbagai bidang hukum yang ada, baik hukum pidana, perdata, tata usaha negara dan lain-lain, serta internalisasi pada struktur hukum dan budaya hukum Pancasila (Rahayu, 2015).

Pokok-pokok pikiran yang harus menjadi acuan pembangunan hukum adalah sebagai berikut. Pertama, hukum itu berwatak mengayomi/melindungi segenap bangsa dan tumpah darah Indonesia, berdasarkan persatuan dalam rangka mewujudkan keadilan sosial bagi seluruh rakyat Indonesia; kedua, hukum harus mampu mewujudkan keadilan sosial bagi seluruh rakyat Indonesia; ketiga, hukum berasal dari rakyat dan mempunyai sifat kerakyatan atau dengan kata lain adanya prinsip kedaulatan rakyat; dan keempat, hukum berdasarkan nilai Ketuhanan Yang Maha Esa, yang memberikan dasar pengaturan terhadap adanya hukum-hukum Tuhan, di samping memperhatikan nilai-nilai kemanusiaan, nilai-nilai moral, dan budi pekerti yang luhur (Kuat Puji Prayitno, 2011).

Sudah sepantasnya manusia Indonesia memiliki karakter yang selalu berdimensi dua di mana untuk menjalankan hukum pun haruslah sesuai dengan kodrat dan sifat manusia demi kepentingan bersama dalam lingkup sosial. Oleh karena itu posisi
Pancasila harus kembali menjadi dasar setiap pribadi manusia Indonesia dalam menjalankan hukum dan bukan sekedar sebagai garnis atau pemanis dalam melakukan setiap tindakan hukum (Putra, 2014).

Lebih konkret lagi, dalam rumusan kurikulum pendidikan tinggi hukum di Indonesia yang berkarakter lintas budaya berdasarkan nilai-nilai Pancasila setidaknya ada beberapa mata kuliah yang wajib dicantumkan, antara lain Pendidikan Pancasila, filsafat Pancasila, atau bahkan di setiap mata kuliah yang ada diinternalisasi nilai-nilai Pancasila di dalamnya. Pada saat ini hukum yang berkarakter lintas budaya sebagai hasil pendidikan tinggi hukum yang berkarakter Pancasila mulai bermunculan, salah satunya adalah pluralisme hukum. Pluralisme hukum berpijak tidak hanya pada satu jenis hukum tetapi juga melihat hukum yang lainnya, misalnya, selain hukum negara dilihat, juga di lihat hukum yang dibuat masyarakat lokal dan hukum agama yang memuat ajaran moral.

Pendidikan tinggi hukum yang berkarakter pluralisme hukum setidaknya telah membuka ruang untuk tidak hanya melihat hukum itu satu, yakni hukum yang di buat negara, melainkan hukum itu ada juga di masyarakat atau bahkan di buat oleh masyarakat dalam mengatur kehidupannya sehari-hari. Menghargai keanekaragaman dalam hukum ini merupakan salah satu bentuk hukum Pancasila itu sendiri. Pancasila selalu bias mewarnai nilai-nilai baru yang masuk (Fuad, 2013).

Pola sikap bangsa Indonesia dalam menghadapi keaneka-ragaman ini berdasar pada suatu semboyan yakni "Bhinneka Tunggal Ika". Dalam menerapkan pluralitas dalam kehidupan, bangsa Indonesia mengacu pada prinsip yang terkandung dalam Pembukaan UUD 1945, bahwa yang diutamakan adalah kepentingan bangsa bukan kepentingan individu (Latif, 2011), berikut frase-frase yang terdapat dalam Pembukaan UUD 1945:

a. Bahwa sesungguhnya kemerdekaan itu ialah hak segala bangsa; 
b. Bahwa kemerdekaan yang dinyatakan oleh bangsa Indonesia, supaya rakyat dapat berkehidupan kebangsaan yang bebas;

c. Bahwa salah satu misi Negara-bangsa Indonesia adalah untuk mencerdaskan kehidupan bangsa;

d. Bahwa salah satu dasar Negara Indonesia adalah Persatuan Indonesia, yang tiada lain merupakan wawasan kebangsaan.

e. Bahwa yang ingin diwujudkan dengan berdirinya Negara-bangsa Indonesia adalah keadilan sosial bagi seluruh rakyat Indonesia.

Dari frase-frase yang terdapat dalam Pembukaan UUD 1945 tersebut jelas bahwa prinsip kebangsaan mewarnai kehidupan berbangsa dan bernegara bagi bangsa Indonesia. Istilah individu atau konsep individualisme tidak terdapat dalam Pembukaan UUD 1945. Dengan kata lain bahwa pluralistik yang diterapkan di Indonesia tidak berdasar pada individualisme dan liberalisme.

Pluralitas atau pluralistik tidak merupakan suatu faham, isme atau keyakinan yang bersifat mutlak (L.Tanya, 2015). Untuk itu tidak perlu dikembangkan ritual-ritual tertentu seperti halnya agama. Pluralistik yang diambil oleh bangsa Indonesia sebagai salah satu prinsip dalam penyelenggaraan kehidupan berbangsa dan bernegara memiliki ciri-ciri sebagai berikut:

1. Pluralistik mengandung pengertian bahwa dalam kehidupan bersama dilandasi oleh sikap inklusif, yang bermakna bahwa dalam berhubungan dengan pihak lain tidak bersikap menang-nya sendiri, bahwa pendapatnya tidak mesti yang paling benar, tidak meremehkan pendapat pihak lain.

2. Sikap pluralistik tidak bersifat sektarian dan eksklusif yang terlalu membanggakan kelompoknya sendiri dan tidak memperhitungkan kelompok lain. Sebagai akibat berkembang sikap curiga, cemburu dan berlangsung persaingan yang kurang sehat.

3. Sikap pluralistik tidak bersifat formalistik belaka, yang hanya menunjukkan perilaku semu. Sikap pluralistik dilandasi oleh sikap saling percaya mempercayai dan saling hormat menghormati. Bahkan harus didasari oleh rasa kasih sayang sehingga dapat mempersatukan keanekaragaman dalam kerukunan.

4. Sikap pluralistik mengarah pada tindakan konvergen bukan divergen.

5. Sikap pluralistik tidak bersifat ekspansif, sehingga lebih mementingkan kualitas dari pada kuantitas.

6. Bersikap toleran, memahami pihak lain serta menghormati dan menghargai pandangan pihak lain

7. Sikap pluralistik tidak menyentuh hal-hal yang bersifat sensitif pada pihak lain.

8. Sikap pluralistik bersifat akomodatif dilandasi oleh kedewasaan dan pengendalian diri secara prima. Sikap pluralistik bersifat sportif, berani mengakui keunggulan dan kelemahan diri dan mitra kerja atau mitra bertanding.

9. Sikap pluralistik menghindari sikap ekstrimitas, mengmbangkan sikap moderat, berimbang dan proporsional.

Pendidikan tinggi hukum berbasis Pancasila artinya, pendidikan yang mengajarkan dan menerapkan nilai-nilai pluralisme atau keberagaman. Keberagaman dalam bidang hukum adalah keberagaman yang menunjukkan di Indonesia berlaku lebih dari satu hukum, yakni hukum agama, hukum adat dan hukum nasional yang memiliki hubungan saling menguatkan (Sastra Wibawa, 2016b).

\section{KESIMPULAN}

Pancasila sebagai dasar budaya bangsa tentunya menjadi dasar dalam pendidikan tinggi di Indonesia. Khususnya 
dalam pendidikan tinggi hukum yang berkarakter Pancasila akan menghasilkan pendidikan karakter yang menjunjung tinggi nilai kemanusiaan, nilai persatuan, nilai demokrasi dan nilai keadilan yang didasarkan atas nilai Ketuhanan Yang Maha Esa

\section{Daftar Pustaka}

Amarini, I. (2017). Evaluasi Aktualisasi Pancasila Melalui Harmonisasi Hukum. Jurnal Kosmik Hukum, 17(2), 88.

Fuad, F. (2013). Filsafat Hukum Pancasila: Antara Cita Ideal Hukum Dan Nilai Praksis. Jurnal Ilmiah Mimbar Demokrasi, 13(1), 2013.

Hafidz, J. (2018). Karakteristik Kebijakan Pendidikan Tinggi Hukum Indonesia Berdasarkan Pancasila Dan UndangUndang Dasar Negara Republik Indonesia Tahun 1945. Kertha Wicaksana, 1(1), 24.

Kuat Puji Prayitno. (2011). Pancasila Sebagai "Screening Board" Dalam Membangun Hukum Di Tengah Arus Globalisasi Dunia Yang Multidimensional. Jurnal Dinamika Hukum, 1(11).

L.Tanya, B. (2015). Pancasila Bingkai Hukum Indonesia. Yogyakarta: Genta Publising.

Latif, Y. (2011). Negara Paripurna (Historisitas, Rasionalitas, dan Aktualitas Pancasila). Jakarta: Gramedia Pustaka Utama.

Oksep Adhayanto. (2015). Implementasi Nilai-Nilai Pancasila Sebagai Dasar Negara Dalam Pembentukkan Peraturan Perundang-Undangan. Jurnal Ilmu Hukum, 5(2), 1.

Putra, S. D. E. (2014). Bingkai Keadilan Hukum Pancasila Dalam Perspektif Hukum Dan Relevansinya Dengan Keadilan Di Indonesia. Jurnal Pendidikan Pancasila Dan Kewarganegaraan, 27(1), 57.
Rahayu, D. P. (2015). Aktualisasi Pancasila Sebagai Landasan Politik Hukum Indonesia. Yustisia, 4(1), 200.

Sastra Wibawa, I. P. (2016a). HIGHER EDUCATION LAW CHARACTERLESS PANCASILA. In DHARMA ACARYA FACULTY INTERNATIONAL SEMINAR (DAFIS) PROCEEDING (pp. 166-170). Denpasar: Jaya Pangus Press. Retrieved from

http://proceedings.jayapanguspress.org/i ndex.php/dp/article/view/149/149

Sastra Wibawa, I. P. (2016b). Politik Hukum Perlindungan dan Pengelolaan Lingkungan Menuju Ekokrasi Indonesia. Kanun Jurnal Ilmu Hukum, 18(1), 51-68. Retrieved from http://www.jurnal.unsyiah.ac.id/kanun/a rticle/view/5918/4872

Sutrisno. (2016). Peran Ideologi Pancasila Dalam Perkambangan Konstitusi Dan Sistem Hukum Dindonesia. Jurnal Pancasila Dan Kewarganegaraan, 1(1), 1. 